The Bangladesh Veterinarian (2019) 36(1 - 2): 25 - 32

\title{
Effects of aloe vera (Aloe barbadensis Miller) gel on growth performance and haemato-biochemical profiles in broiler chickens
}

\author{
MM Islam, KKI Khalil, MA Islam, KM Sujan, A Mustari and MA Miah*
}

Department of Physiology, Faculty of Veterinary Science, Bangladesh Agricultural University, Mymensingh-2202, Bangladesh

\begin{abstract}
The study was designed to assess the effects of aloe vera gel (AVG) on broiler growth performance and haemato-biochemical changes. "Lohman" day-old broiler chicks $(n=48)$ were reared for 28 days. At day 13, chicks were randomly divided into four equal groups (12/group). Group A was non-treated control. Group B was supplemented with antibiotic (oxytetracycline hydrochloride) as a growth promoter in water. Group C and D were supplied AVG (1\% and $2 \%)$ in drinking water. Antibiotic and AVG treated broilers had higher $(\mathrm{P}<0.05)$ live weight $(1803.8 \pm 63.6 \mathrm{gm}$ and $1800.00 \pm 64.2 \mathrm{gm})$ than control $(1607.5 \pm$ $41.7 \mathrm{gm})$. Total erythrocyte count $\left(3.6 \pm 0.1 \times 10^{6} / \mathrm{uL}\right)$, haemoglobin $(9.9 \pm 0.1 \mathrm{gm} \%)$ and packed cell volume $(35.2 \pm 0.4 \%)$ were higher $(\mathrm{P}<0.05)$ in treated groups. It is suggested that the aloe vera gel supplementation $(1-2 \%)$ may be used as an alternative to antibiotics for better growth performance in broilers without deleterious effects on haematobiochemical profiles. (Bangl. vet. 2019. Vol. 36, No. 1 - 2, 25 - 32)
\end{abstract}

\section{Introduction}

Antibiotics are routinely used as growth promoters in poultry feeds (Houshmand et al., 2011; Saleh, 2014). Continuous use of antibiotics in feed is suspected to increase resistance of pathogens, accumulation of antibiotic residues in animal products and the environment, and change gut microflora (Shokraneh et al., 2016). Plant feed additives are alternatives to growth promoters, and have gained widespread attention in the feed industry (Pathak et al., 2016). Some aromatic plants and essential oils (EO) extracted from these plants have antimicrobial properties, stimulating effects on animal digestive systems, and antioxidant properties (Wenk, 2003). Aloe vera (AV) has been used for therapeutic purposes. This member of Liliaceae looks like a cactus and grows in arid regions of Asia and Africa (Boudreau and Beland, 2006). The leaf consists of latex and gel. The gel is $98.5 \%$ to $99.5 \%$ water (Femenia et al., 1999), and contains more than 75 biologically active ingredients, which are useful in treating diseases (Boudreau and Beland, 2006). AV gel contains compounds with antibacterial, antiviral, antifungal, antioxidant, anti-inflammatory, anti-diabetic, immunomodulatory, and wound healing properties (Christaki and Florou-Paneri, 2010). It also contains acemannan, which can affect the humoral immune reaction and cellular

\footnotetext{
*Corresponding author:- E-mail: mam74@bau.edu.bd
}

DOI: https://doi.org/10.3329/bvet.v36i1-2.55747 
immunity, activating macrophages to release inflammatory cytokines such as interleukin-1 (IL-1), IL-6, and tumour necrosis factor- $\alpha$ (TNF-a). AV gel has antimicrobial properties against pathogenic bacteria including Staphylococcus aureus and Escherichia coli (Shokraneh et al., 2016). Major ingredients of aloe vera include anthraquinones, saccharides, vitamins, enzymes, and low-molecular-weight compounds, which have anti-inflammatory, immunomodulatory, wound-healing, anti-viral, anti-fungal, anti-tumour, anti-diabetic, and anti-oxidant effects (Choi and Chung, 2003; Akhtar et al., 2012). Acemannan can improve the immune response in broilers (Valle-paraso et al., 2005). One percent aloe vera leaf powder improved body weight and can be used as an alternative for antibiotic growth promoters (Mmereole, 2008) and improved the humoral immunity of broilers (Darabighane et al., 2012). Aloe vera has the potential to be a growth promoter in broiler chicks and its growthpromoting effects are comparable to those of antibiotic growth promoters (Singh et al., 2013). Supplementation of aloe vera in broilers decreased the mortality, and the cost of feed decreased by 6.2 to $13.5 \%$ (Eevuri and Putturu, 2013). AVG inclusion at 20 $\mathrm{ml} /$ litre in drinking water could successfully replace antibiotics in turkey poults (Bolu et al., 2013). The study was designed to know the effects of AVG on growth performance, haemato-biochemical profile and liver and kidney functions.

\section{Materials and Methods}

\section{Experimental birds}

Lohman commercial broiler chicks $(n=48)$ were used and reared following standard procedures up to 12 days.

\section{Experimental design}

A completely randomized design was followed. On the 13th day of age, chicks were randomly divided into four groups each of 12 birds, kept in different cages. Group A was kept as untreated control. Group B was administered the recommended therapeutic dose of Oxytetracycline Hydrochloride-200 mg soluble powder (Renamycin ${ }^{\circledR}$; Renata Limited, Animal Health Division, Dhaka, Bangladesh)@ 1 gm/L in drinking water. Group C and D were administered AVG from leaf extract at a rate of 1 and $2 \%$ in the drinking water. Treatments continued up to the age of 28 days. Birds received their freshly prepared daily medication each morning and afternoon. The concentration of oxytetracycline in the water to give the required dose per kilogram of body weight was calculated by determining the water consumption and body weight of each bird on the day of medication.

\section{Collection and processing of $A V G$}

Fresh Aloe leaves were collected from the local market for the extraction of gel. The leaves were cleaned with water and the aloe vera gel was extracted from the leaf manually by cutting. Latex of the leaf was removed, and the gel was collected into a beaker. Concentrated $\{10 \%(\mathrm{w} / \mathrm{v}) \& 20 \%(\mathrm{w} / \mathrm{v})\}$ infusion was prepared by taking 100 gm and $200 \mathrm{gm}$ of fresh gel in two different glass bottles, and one litres of hot boiled 
distilled water was poured into each bottle. The bottles were shaken for 5 - 7 min to ensure thorough mixing and kept for 6-8 $\mathrm{h}$ at room temperature.

\section{Measurements of weight and feed conversion ratio (FCR)}

The body weight of each bird was measured weekly at 14, 21 and 28 days of age and total body weight gain was calculated. Feed Conversion Ratio (FCR) was calculated from total feed consumed by birds divided by total weight gain. Feed intake was the difference between the quantity of feed supplied to the birds and the amount of feed that remained at the end of every feeding period.

\section{Blood collection and preparation of serum}

Blood samples were collected into sterile vials with anti-coagulant vials during the sacrifice and were immediately stored in the refrigerator. Blood was also collected into plain tubes, which were kept for $2-3 \mathrm{~h}$, then serum was separated. The sera were stored in deep freeze $\left(-20^{\circ} \mathrm{C}\right)$.

\section{Haemato-biochemical analysis}

Haemoglobin $(\mathrm{Hb})$, Total Erythrocyte Count (TEC) and Packed Cell Volume (PCV) were analysed within two hours of the collection as described by Salahuddin et al. (2012). The serum total cholesterol, triglycerides, high-density lipoproteins (HDL), low-density lipoproteins (LDL), creatinine, alanine aminotransferase (ALT) and aspartate aminotransferase (AST) were estimated according to Haque et al. (2017) using a UV spectrophotometer T 80, PG Instruments, Great Britain.

\section{Statistical analysis}

The data were recorded in Microsoft Excel-2010 and imported to the software Graph Pad Prism 7 for analysis. The haematological and biochemical parameters corresponding to AVG supplementation were compared by performing ANOVA as described by Steel and Torrie (1980).

\section{Results and Discussion}

\section{Effects of $A V G$ and antibiotic on growth performance}

At $14^{\text {th }}$ and 21 st day, the body weight was similar $(\mathrm{P}>0.05)$ among four groups (Table 1).

On the $28^{\text {th }}$ day of age, body weights were significantly higher in the treated groups than in control. The highest body weights were in group B (1803.8 $\pm 63.6 \mathrm{gm})$ and group D (1800.00 $\pm 64.2 \mathrm{gm})$ and the lowest $(1607.5 \pm 41.7 \mathrm{gm})$ in group A (control). The increased body weight gains in the treated group (group B, C and D) might be due to an increased feed utilization and metabolism of supplied feed nutrients. The result coincides with the findings of Darabighane et al. (2011) who stated that AVG brought about higher body weight gain and feed intake compared to the control. No significant difference was seen between the group treated with 2\% AVG and those 
treated with the antibiotic $(\mathrm{P}>0.05)$. The treated groups also had higher body weight gain. The results are in line with the findings of Shokraneh et al. (2016) who reported that dietary herbal growth promoters in birds supplemented with antibiotic had the best feed conversion ratio (FCR): supplementation of $0.5 \%$ and $0.8 \% \mathrm{AV}$ improved FCR compared with control group $(\mathrm{P}<0.05)$.

Table 1: Effects of aloe vera gel on live body weight (BW) Body weight gain (BWG) and Feed conversion ratio (FCR) in broiler chickens

\begin{tabular}{l|c|c|c|c|c}
\hline \multirow{2}{*}{ Groups } & \multicolumn{3}{|c|}{ BW (gm) (Mean \pm SEM) } & BWG (gm) & FCR \\
\cline { 2 - 5 } & $14^{\text {th }}$ day & $21^{\text {st }}$ day & $28^{\text {th }}$ day & & \\
\hline $\begin{array}{l}\text { Group A } \\
\text { (Control) }\end{array}$ & $526.3 \pm 18.8^{\text {ns }}$ & $1115.6 \pm 6.9^{\mathrm{ns}}$ & $1607.5 \pm 41.7^{\mathrm{a}}$ & $1081.3 \pm 42.1^{\mathrm{a}}$ & $1.5 \pm 0.1^{\mathrm{a}}$ \\
$\begin{array}{l}\text { Group B } \\
\text { (Antibiotics) }\end{array}$ & $534.0 \pm 26.7^{\mathrm{ns}}$ & $1186.9 \pm 35.9^{\mathrm{ns}}$ & $1803.8 \pm 63.6^{\mathrm{b}}$ & $1269.8 \pm 44.4^{\mathrm{b}}$ & $1.3 \pm 0.0^{\mathrm{b}}$ \\
$\begin{array}{l}\text { Group C } \\
\text { (AVG-1\%) }\end{array}$ & $566.9 \pm 16.4^{\mathrm{ns}}$ & $1156.3 \pm 22.9^{\mathrm{ns}}$ & $1789.4 \pm 41.7^{\mathrm{b}}$ & $1222.5^{2} \pm 50.3^{\mathrm{b}}$ & $1.3 \pm 0.1^{\mathrm{b}}$ \\
$\begin{array}{l}\text { Group D } \\
\text { (AVG-2\%) }\end{array}$ & $548.75 \pm 15.7^{\mathrm{ns}}$ & $1263.13 \pm 30 .^{\mathrm{ns}}$ & $1800.00 \pm 64.2^{\mathrm{b}}$ & $1255.0 \pm 46.5^{\mathrm{b}}$ & $1.3 \pm 0.0^{\mathrm{b}}$ \\
P-Value & 0.5277 & 0.0675 & 0.0420 & 0.027 & 0.018 \\
\hline
\end{tabular}

$\mathrm{a}, \mathrm{b}$ Values with different superscript letters in a column differs significantly $(\mathrm{P}<0.05)$ and ns-Not significant

The average feed eaten by each group was $1623 \mathrm{gm}$ and the feed conversion ratio (FCR) was 1.5, 1.3, 1.3 and 1.3 in groups A, B, C and D, respectively. Previous reports stated that AVG added to water resulted in significantly higher body weight gain (Darabighane et al., 2011; Olupona et al., 2010). Aloe vera groups showed a lower feed conversion ratio than the control group and the difference was significant $(\mathrm{P}<0.05)$ as shown in Table 1.

\section{Effects of AVG and antibiotic on haemato-biochemical parameters}

$\mathrm{Hb}$, TEC and PCV values are presented in Table 2.

Table 2: Haematological parameters (Hb, TEC, PCV) (Mean \pm SEM) of broiler chickens in different treatment groups

\begin{tabular}{l|c|cc}
\hline \multicolumn{1}{c}{ Groups } & $\mathrm{Hb}(\mathrm{gm} \%)$ & $\mathrm{TEC}\left(\times 10^{6} / \mu \mathrm{L}\right)$ & $\mathrm{PCV}(\%)$ \\
\hline Group A (Control) & $7.9 \pm 0.01^{\mathrm{a}}$ & $2.3 \pm 0.1^{\mathrm{a}}$ & $30.0 \pm 0.6^{\mathrm{a}}$ \\
Group B (Antibiotics) & $9.5 \pm 0.01^{\mathrm{b}}$ & $3.3 \pm 0.0^{\mathrm{b}}$ & $36.8 \pm 0.4^{\mathrm{b}}$ \\
Group C (AVG-1\%) & $9.2 \pm 0.1^{\mathrm{b}}$ & $2.9 \pm 0.0^{\mathrm{b}}$ & $34.2 \pm 0.5^{\mathrm{b}}$ \\
Group D (AVG-2\%) & $9.9 \pm 0.1^{\mathrm{b}}$ & $3.6 \pm 0.1^{\mathrm{b}}$ & $35.2 \pm 0.4^{\mathrm{b}}$ \\
P-Value & 0.0001 & 0.0012 & 0.0003 \\
\hline
\end{tabular}

$\mathbf{A}, \mathbf{b}$ values with different superscript letters in a column differs significantly $(\mathrm{p}<0.05)$ and NS-Not significant. 
The highest $\mathrm{Hb}(9.9 \pm 0.1 \mathrm{gm} \%)$ concentration was recorded in group D (AVG-2\%), the second-highest $\mathrm{Hb}$ concentration $(9.5 \pm 0.01 \mathrm{gm} \%)$ in group $\mathrm{B}$ (antibiotic) and the lowest in group A $(7.9 \pm 0.01 \mathrm{gm} \%)$. Aloe vera supplementation increased the $\mathrm{Hb}$ concentration $(9.9 \pm 0.1 \mathrm{gm} \%)$ significantly. The highest TEC was recorded in group D $\left(3.6 \pm 0.1 \times 10^{6} / \mu \mathrm{L}\right)$ followed by group $\mathrm{B}\left(3.3 \pm 0.1 \times 10^{6} / \mu \mathrm{L}\right)$ and the lowest in group $\mathrm{A}$ $\left(2.3 \pm 0.1 \times 10^{6} / \mu \mathrm{L}\right)$. The highest PCV was in group $\mathrm{B}(36.8 \pm 0.4 \%)$ and group $\mathrm{D}(35.2 \pm$ $0.4 \%)$ and the lowest was in group A $(30.0 \pm 0.6 \%)$. The differences between control and treatement groups were significant $(\mathrm{P}<0.05)$. AVG significantly $(\mathrm{P}<0.05)$ increased PCV values. The birds fed diets containing both AVG $1 \%$ and AVG $2 \%$ had significantly $(\mathrm{P}<0.05)$ higher haematological values than control groups $(\mathrm{P}<0.05)$ but comparable to antibiotic groups. The increased haematological values in the treated groups could be attributed to the action of haemapoietic stimulating nutrients in the aloe vera supplied. These results agree with Singh et al. (2013) who showed significantly $(\mathrm{P}<0.05)$ higher $\mathrm{Hb}$ concentration and $\mathrm{PCV}$. Total cholesterol, triglyceride, HDL and LDL (Table 3) did not differ significantly between the groups, which indicated that inclusion of AVG in feed had no detrimental effects on bird's lipid profile. Tariq et al. (2014) showed no effect on total cholesterol or triglycerides after supplementation with aloe vera and clove.

Table 3: Effects of AVG and antibiotic on lipid profile (Mean \pm SEM) of broiler chickens

\begin{tabular}{l|c|c|c|c}
\hline \multicolumn{1}{c|}{ Groups } & $\begin{array}{c}\text { Total cholesterol } \\
(\mathrm{mg} / \mathrm{dl})\end{array}$ & $\begin{array}{c}\text { Triglyceride } \\
(\mathrm{mg} / \mathrm{dl})\end{array}$ & HDL $(\mathrm{mg} / \mathrm{dl})$ & LDL $(\mathrm{mg} / \mathrm{dl})$ \\
\hline $\begin{array}{l}\text { Group A } \\
\text { (Control) }\end{array}$ & $151.6 \pm 1.6^{\mathrm{ns}}$ & $86.0 \pm 2.6^{\mathrm{ns}}$ & $39.2 \pm 0.6^{\mathrm{ns}}$ & $95.3 \pm 1.1^{\mathrm{ns}}$ \\
$\begin{array}{l}\text { Group B } \\
\text { (Antibiotics) }\end{array}$ & $163.7 \pm 4.3^{\mathrm{ns}}$ & $92.2 \pm 5.6^{\mathrm{ns}}$ & $37.8 \pm 0.9^{\mathrm{ns}}$ & $100.8 \pm 4.8^{\mathrm{ns}}$ \\
$\begin{array}{l}\text { Group C } \\
\text { (AVG-1\%) }\end{array}$ & $151.0 \pm 2.8^{\mathrm{ns}}$ & $83.4 \pm 2.1^{\mathrm{ns}}$ & $37.15 \pm 1.2^{\mathrm{ns}}$ & $96.9 \pm 3.1^{\mathrm{ns}}$ \\
$\begin{array}{l}\text { Group D } \\
\text { (AVG-2\%) }\end{array}$ & $150.5 \pm 2.6^{\mathrm{ns}}$ & $91.8 \pm 2.5^{\mathrm{ns}}$ & $38.2 \pm 0.5^{\mathrm{ns}}$ & $92.5 \pm 1.9 \mathrm{~ns}$ \\
P-Value & 0.380 & 0.097 & & 0.019 \\
\hline
\end{tabular}

*NS-Not significant.

The mean values of creatinine and ALT were similar in all groups (Table 4). In the case of AST, the values of group B (antibiotic) were significantly $(\mathrm{P}<0.05)$ higher $(12.8$ $\pm 1.5 \mathrm{U} / \mathrm{L})$ than in other groups $(6.9 \pm 0.5 \mathrm{U} / \mathrm{L})$. When the liver is damaged, AST rises. Increasing AST can indicate damage to heart or kidneys. The results are similar to those obtained by Mehala and Moorthy, (2008); Singh et al. (2013). 
Table 4: Effects of AVG and antibiotic on serum creatinine, ALT and AST values of broiler chickens

\begin{tabular}{lcccc}
\hline \multicolumn{1}{c|}{ Groups } & Creatinine $(\mathrm{mg} / \mathrm{dL})$ & ALT $(\mathrm{U} / \mathrm{L})$ & AST $(\mathrm{U} / \mathrm{L})$ \\
\hline Group A (Control) & $0.8 \pm 0.1^{\mathrm{ns}}$ & $4.8 \pm 0.3^{\mathrm{ns}}$ & $6.9 \pm 0.5^{\mathrm{a}}$ \\
Group B (Antibiotics) & $0.8 \pm 0.2^{\mathrm{ns}}$ & $5.7 \pm 0.7^{\mathrm{ns}}$ & $12.8 \pm 1.5^{\mathrm{b}}$ \\
Group C (AVG-1\%) & $1.0 \pm 0.1^{\mathrm{ns}}$ & $4.3 \pm 0.4^{\mathrm{ns}}$ & $5.6 \pm 0.5^{\mathrm{a}}$ \\
Group D (AVG-2\%) & $1.0 \pm 0.1^{\mathrm{ns}}$ & $4.4 \pm 0.3^{\mathrm{ns}}$ & $8.3 \pm 1.2^{\mathrm{a}}$ \\
P-Value & 0.390 & 0.0971 & 0.019 \\
\hline
\end{tabular}

$\mathbf{A}, \mathbf{b}$ values with different superscript letters in a column differs significantly $(P<0.05)$ and ns-Not significant.

\section{Conclusions}

AVG supplemented broilers had higher $(\mathrm{P}<0.05)$ live weight than controls, comparable to birds treated with antibiotics. TEC, $\mathrm{Hb}$ and PCV were higher $(\mathrm{P}<0.01)$ in AVG supplemented birds. AST values were increased in birds fed AVG $2 \%$ and antibiotics. Treatment of broilers with AVG appears to be as safe as antibiotic. Further studies are needed to investigate the molecular mechanism of action in AVG as well as the tolerance level.

\section{Acknowledgements}

This research work was supported by the National Science and Technology (NST) fellowship funded by the Ministry of Science and Technology, Government of the People's Republic of Bangladesh for MS degree to the first author of this article (Grant No. 1844/138/2017-2018).

\section{References}

Akhtar M, Hai A, Awais MM, Iqbal Z, Muhammad F, Anwar MI 2012: Immunostimulatory and protective effects of Aloe vera against coccidiosis in industrial broiler chickens. Veterinary Parasitology 186 170-177.

Bolu SA, Babalola TO, Elelu N, Ahmed RN, Oyetunde SA, Ademola PF 2013: Effect of supplemental Aloe vera gel in drinking water on some performance histology, haematology, serum constituents and growth of turkey poults challenged with Escherichia coli. Wudpecker Journal of Agriculture Research 2 223-229.

Boudreau MD, Beland FA 2006: An evaluation of the biological and toxicological properties of Aloe barbadensis (Miller) Aloe vera. Journal of Environmental Science and Health 24 103-154.

Choi S, Chung MH 2003: A review on the relationship between Aloe vera components and their biologic effects. Seminars in Integrative Medicine 1 53-62. 
Christaki EV, Panagiota C, Paneri F 2010: Aloe vera: A plant for many uses. Journal of Food, Agriculture and Environment 8 245-249.

Darabighane B, Zarei A, Shahneh AZ, Mahdavi A 2011: Effects of different levels of Aloe vera gel as an alternative to antibiotic on performance and ileum morphology in broilers. Italian Journal Animal Science 10 189-194.

Darabighane B, Zarei A, Shahneh AZ 2012: The effects of different levels of Aloe vera gel on ileum microflora population and immune response in broilers: a comparison to antibiotic effects. Journal of Applied Animal Research 40 31-36.

Eevuri TR, Putturu R 2013: Use of certain herbal preparations in broiler feeds - A review. Veterinary World 6 172-179.

Femenia A, Sanchez ES., Simal S, Rossello C 1999: Compositional features of polysaccharides from Aloe vera (Aloe barbadensis Miller) plant tissues. Carbohydrate Polymer 39 109-117.

Haque MI, Ahmed N, Miah MA 2017: Comparative analysis of body weight and serum biochemistry in broilers supplemented with some selected probiotics and antibiotic growth promoters. Journal of Advanced Veterinary and Animal Research 4 288-294.

Houshmand M, Azhar K, Zulkifli I, Bejo MH, Meimandipour A, Kamyab A 2011: Effects of non-antibiotic feed additives on performance, tibia dyschondroplasia incidence and tibia characteristics of broilers fed low calcium diets. Journal of Animal Physiology and Animal Nutrition 95 351-358.

Mehala C, Moorthy M 2008: Effect of Aloe vera and Curcuma longa (turmeric) on carcass characteristics and biochemical parameters of broilers. International Journal of Poultry Science 7 857-861.

Mmereole F 2008: Evaluation of the dietary inclusion of Aloe vera as an alternative to antibiotic growth promoter in broiler production. Pakistan Journal of Nutrition 10 1-5.

Olupona JA, Omotoso OR, Adeyeye AA, Kolawole OD, Airemionkhale AP, Adejinmi OO et al. 2010: Effect of Aloe vera juice application through drinking water on performance, carcass characteristics, haematology and organoleptics properties in broilers. Poultry Science 88(E-Suppl. 1) 4

Pathak M, Mandal GP, Patra AK, Samanta I, Pradhan S, Haldar S 2016: Effects of dietary supplementation of cinnamaldehyde and formic acid on growth performance, intestinal microbiota and immune response in broiler chickens. Animal Production Science 57 821-827.

Salahuddin M, Miah MA, Ahmed N 2012: Effects of protein and ADE on growth performance and haemato-biochemical profile in broiler. Bangladesh Journal of Veterinary Medicine 10 9-14.

Saleh AA 2014: Nigella seed oil as alternative to avilamycin antibiotic in broiler chicken diets. South African Journal of Animal Science 44 254-262. 
Shokraneh M, Ghalamkari G, Toghyani M, Landy N 2016: Influence of drinking water containing Aloe vera (Aloe barbadensis Miller) gel on growth performance, intestinal microflora, and humoral immune responses of broilers. Veterinary World 9 1197-1203.

Singh J, Koley KM, Chandrakar K, Pagrut NS 2013: Effects of aloe vera on dressing percentage and haemato-biochemical parameters of broiler chickens. Veterinary World 6 803-806.

Steel RGD, Torrie JH 1980. Principles and Procedures of Statistics, A biometrical approach (2nd edition). McGraw-Hill, New York, USA, pp. 20-90.

Tariq H, Raman Rao PV, Mondal BC, Malla BA 2014: Effect of Aloe Vera (Aloe barbadensis) and Clove (Syzigium aromaticum) supplementation on immune status, haematological and serum biochemical parameters in Japanese Quails. Indian Journal of Animal Nutrition 31 293-296.

Valle-Paraso M, Vidamo P, Anunciado R, Lapitan A 2005: Effects of Aloe vera (Aloe barbadensis) on the white blood cell count and antibody titre of broiler chickens vaccinated against Newcastle disease. Philippino Journal of Veterinary Medicine 42 49-52.

Wenk C 2003: Herbs and botanicals as feed additives in monogastric animals. AsianAustralian Journal of Animal Science 16 282-289. 